\title{
Biological Activity of Piper aduncum extracts on Anticarsia gemmatalis (Hübner) (Lepidoptera: Erebidae) and Spodoptera frugiperda (J.E. Smith) (Lepidoptera: Noctuidae)
}

\author{
DAIANE C. LUCENA ${ }^{1}$, LUCIA R. BERTHOLDO-VARGAS ${ }^{1}$, WILSON C. SILVA ${ }^{2}$, AARON \\ F. MACHADO ${ }^{1}$, TAMIRIS S. LOPES ${ }^{1}$, SIDNEI MOURA ${ }^{1}$ and NEIVA M. BARROS ${ }^{1}$ \\ ${ }^{1}$ Instituto de Biotecnologia, Universidade de Caxias do Sul, Rua Francisco \\ Getúlio Vargas, 1130, 95070-560 Caxias do Sul, RS, Brazil \\ ${ }^{2}$ Programa de Pós-graduação em Biotecnologia e Recursos Naturais da Amazônia, Universidade do \\ Estado do Amazonas, Av. Djalma Batista, 3578, Flores, 69050-010 Manaus, AM, Brazil
}

Manuscript received on March 16, 2017; accepted for publication on April 10, 2017

\begin{abstract}
Piper aduncum found naturally in the Amazon and southeastern Brazil, is known for its secondary metabolites that have activity on insects. Anticarsia gemmatalis and Spodoptera frugiperda are among the major insect pests associated with agricultural production. This research evaluated the biological activity of hexane, ethyl acetate, and ethanol extracts of $P$. aduncum leaves on mortality and duration of larval and pupal periods, as well as weight, width, and length of A. gemmatalis and S. frugiperda pupae. The mortality of A. gemmatalis larvae in trials with P. aduncum extracts were $93.3 \%$ (hexane) and $90 \%$ (ethyl acetate), estimating $\mathrm{LC}_{50}$ of 6.35 and $5.79 \mathrm{mg} / \mathrm{mL}$, respectively. Mortality in $S$. frugiperda submitted to the hexane extract ranged from $3.33 \%$ to $96.66 \%\left(\mathrm{LC}_{50}\right.$ of $\left.8.22 \mathrm{mg} / \mathrm{mL}\right)$. The ethanol extract induced low mortality (3.33\% to $23.33 \%$ ). The P. aduncum extracts did not affect the development of $S$. frugiperda pupae. In A. gemmatalis differences in weight and length occurred. The chemical characterization was by GC-MS, which revealed that the major constituent in the hexane extract of $P$. aduncum was apiol (90.7\%). P. aduncum extracts are important and promising components to manage A. gemmatalis and S. frugiperda, which cause extensive production losses.
\end{abstract}

Key words: fall armyworm, velvetbean caterpillar, pest management, plant extracts.

\section{INTRODUCTION}

Soybean and corn crops are extensively cultivated in the state of Rio Grande do Sul, Brazil, thereby forming very simplified and vulnerable agroecosystems. Along with the benefits of these crops, problems have arisen such as the indiscriminate use of pesticides, which have

Correspondence to: Neiva Monteiro de Barros

E-mail: nmbarros@ucs.br adverse environment impacts. The overuse of these products has negative ecological consequences for human health, soil and water contamination, and the food chain.

The negative factors of pesticides have encouraged researchers to investigate less harmful control measures. One of the alternatives for controlling Anticarsia gemmatalis (Hübner) (Lepidoptera: Erebidae) and Spodoptera frugiperda (J.E. Smith) (Lepidoptera: Noctuidae) has been the 
use of natural products to facilitate environmentally safer production, which is fundamentally important for family farming and sustainable development.

The great diversity of plants in the world enables research about new products that may replace or reduce the use of synthetic chemical pesticides. Several plants of toxicological significance are from the Amazon region, such as Piper aduncum (Piperaceae). Surveys report that this plant species has antimicrobial (Abreu et al. 2015), insecticidal (Misni et al. 2008, Carmona-Hernández et al. 2014, Volpe et al. 2016), and acaricidal (Silva et al. 2007, 2009) effects. However, no reports in the literature have demonstrated the insecticidal effect of extracts from this plant on A. gemmatalis and S. frugiperda.

Phytochemical studies of the aerial parts of $P$. aduncum have isolated chalcones, flavonones, and dihydrochalcones (Morandim et al. 2009), a high amount of total flavonoid content, followed by phenols, and alkaloids with sesquiterpenes as the major compounds (Arroyo-Acevedo et al. 2015).

The objective of this research was to evaluate the biological activity on $A$. gemmatalis and $S$. frugiperda of hexane, ethyl acetate, and ethanol extracts of $P$. aduncum and chemically characterize these extracts.

\section{MATERIALS AND METHODS}

\section{COLLECTION AND IDENTIFICATION OF} BOTANICAL MATERIAL

P. aduncum leaves were collected in November 2012 (IBAMA - process 02001.004239 / 2013-05) from specimens grown in the Garden of Medicinal Plants of the Universidade Nilton Lins, located in the city of Manaus, AM, Brazil, at latitude $03^{\circ} 03^{\prime}$ $36.5^{\prime \prime} \mathrm{S}$ and longitude $060^{\circ} 00^{\prime} 31.7^{\prime}$ ' $\mathrm{W}$. They were then identified and deposited in the herbarium of the Universidade de Caxias do Sul (HUCS 42569 and HUCS 42570, respectively).

\section{EXTRACTION OF PLANT MATERIAL}

The plant leaves were dried in an oven at $40{ }^{\circ} \mathrm{C}$ for five days and then ground. The extractions were performed using a Soxhlet extractor with eight hours for each extraction. For $200 \mathrm{~g}$ of crushed leaves, three liters of each solvent were used, with a sequence of solvents with increasing polarity: hexane, ethyl acetate, and ethanol. After extraction, the solvents were evaporated by rotary evaporator to obtain the crude extract.

\section{PHYTOCHEMICAL ANALYSIS}

The chemical composition of plant extracts was determined by gas chromatography-mass spectrometry (GC/MS). The analyzes were performed by gas chromatography coupled to mass selective detector, Hewlett Packard 6890 MSD 5973, equipped with HP Chemstation software and Wiley 275 spectral data, using the fused-silica capillary column HP-5MS (30 m X $250 \mathrm{~m}$ ) and $0.5 \mathrm{~m}$ thick film ( Hewlett-Packard, Palo Alto, CA, USA). The column temperature, $60{ }^{\circ} \mathrm{C}(8 \mathrm{~min})$ to $180{ }^{\circ} \mathrm{C}$ at $3{ }^{\circ} \mathrm{C} / \mathrm{min}$, and $20^{\circ} \mathrm{C} / \mathrm{min}$ to $230^{\circ} \mathrm{C}$; injector $220^{\circ} \mathrm{C}$, interface $250{ }^{\circ} \mathrm{C}$; Split ratio of 1:100; He carrier gas (56 kPa); flow $1.0 \mathrm{~mL} / \mathrm{min}$; ionization energy $70 \mathrm{eV}$. The components were identified by a combination of mass spectrum of the Wiley library and comparison with data from literature. (NIST 2016, USA: http://www.nist.gov/)

\section{BIOLOGICAL TESTS}

A. gemmatalis and $S$. frugiperda caterpillars were raised on an artificial diet (Greene et al. 1976) and kept in the insectarium of the Pest Control Laboratory at the Institute of Biotechnology of the Universidade de Caxias do Sul.

The hexane, ethyl acetate, and ethanol extracts of $P$. aduncum were solubilized in Tween-80 5\% $(\mathrm{v} / \mathrm{v})$ at concentrations of $1.0,2.5,5.0,10.0$, and $15.0 \mathrm{mg} / \mathrm{mL}$, previously determined, which were diluted, homogeneously in artificial diet. The 
control group received diet with no extracts. For the biological tests, 30 third instar caterpillars were used for each treatment and one control group, for total of $180 \mathrm{~A}$. gemmatalis caterpillars and 180 S. frugiperda caterpillars. Each caterpillar was individually placed in a $50 \mathrm{~mL}$ plastic cup, along with a moistened cotton ball and $1 \mathrm{~g}$ of artificial diet with extract, then left to feed for seven days. After this period, the surviving caterpillars were fed a diet without addition of extracts. Mortality rates were assessed daily until the pupal stage. The effects measured for the duration of larval and pupal stage included weight, length, and width of the pupa. Bioassays were maintained at room temperature (temperature $25 \pm 1{ }^{\circ} \mathrm{C}$ and relative humidity $70 \pm 5 \%$ ).

\section{STATISTICAL ANALYSIS}

Data were analyzed using the parametric test for analysis of variance (ANOVA), in which the averages were compared by Tukey test ( $\alpha=$ 0.05), with the aid of the Statistical Package for Social Sciences (SPSS for Windows 17.0). The graphics were prepared using the Graph Pad Prism 6.1 software. Probit analysis (Finney 1971) was used to determine the values of the median lethal concentration $\left(\mathrm{LC}_{50}\right)$.

\section{RESULTS AND DISCUSSION}

\section{PHYTOCHEMICAL ANALYSIS OF P. Aduncum}

The chemical characterization is an important step to relate the plants activity with their respective metabolites. The chemical constituents identified in the hexane extract of $P$. aduncum, 92.4\% were phenylpropanoid, with the apiol as the major compound at $90.7 \% ; 5.1 \%$ were sesquiterpenes ( $\beta$-caryophyllene and $\beta$-selinene). In the ethyl acetate and ethanol extracts of $P$. aduncum, phenylpropanoid apiol was identified at $54.9 \%$ and $21.0 \%$, respectively (Table I).
TABLE I

Chemical constituents identified in hexane, ethyl acetate, and ethanol extracts of Piper aduncum leaves.

\begin{tabular}{ccccc}
\hline \multirow{2}{*}{ Entry } & \multirow{2}{*}{ Extract } & $\begin{array}{c}\text { Chemical } \\
\text { constituent }\end{array}$ & $\begin{array}{c}\text { Retention } \\
\text { time }\end{array}$ & $\begin{array}{c}\text { Abundance } \\
\text { (\%) }\end{array}$ \\
\hline 1 & Hexane & apiol & $21: 57$ & 90.7 \\
& Ethyl acetate & & $21: 52$ & 54.9 \\
& Ethanol & & $21: 52$ & 21.0 \\
2 & hexane & $\beta$-caryophyllene & $18: 41$ & 3.6 \\
3 & hexane & $\beta$-selinene & $19: 54$ & 1.5 \\
4 & hexane & myristicin & $20: 00$ & 1.7 \\
\hline
\end{tabular}

The presence of phenylpropanoids and sesquiterpenes (Table I) confirms what was found in the literature for plant species of Piperaceae family (Almeida et al. 2009; Riva et al. 2011; Cruz et al. 2014, Barros et al. 2016). Phenylpropanoid apiol is one of the major components of essential oil from P. aduncum (Santana et al. 2015).

Apiol (90.7\%) was the major compound identified in hexane extract of P. aduncum (Table I). However, Silva et al. (2009) extracted the essential oil from hexane extract of $P$. aduncum leaves and identified phenylpropanoid dillapiol (94.84\%) as the major constituent, and apiol was only $0.38 \%$. Silva et al. (2013) also identified dillapiol (85.17\%) as a major compound in the essential oil extracted from $P$. aduncum leaves. However, our research did not identify dillapiol in the hexane extract of $P$. aduncum. The absence of this chemical constituent may be due to factors such as plant cultivation system and environmental conditions in certain areas, which may interfere with the content and the presence or absence of some constituents of the plant.

The classes of secondary metabolites identified in P. aduncum (Table I) are one of the main features of the Piperaceae plant family. The Piperaceae family has one of the most versatile secondary metabolisms known in botanical families. The metabolites accumulated by species of this plant family are characterized as being derived from the mixed biosynthesis (shikimate/acetate), which 
results mostly in the production of phenylpropanoid and terpenes (Fazolin et al. 2006).

This diversity of compounds reported in the literature depends on the environmental conditions during development or the age of the plant.

INSECTICIDAL ACTIVITY OF HEXANE, ETHYL ACETATE, AND ETHANOL EXTRACTS OF Piper aduncum ON Anticarsia gemmatalis AND Spodoptera frugiperda

Mortality rate of A. gemmatalis and S. frugiperda, subjected to different concentrations of hexane extract of $P$. aduncum leaves, ranged from 3.3 to $93.3 \%$ and from 3.3 to $96.6 \%$, respectively. The concentrations of $5.0,10.0$, and $15.0 \mathrm{mg} / \mathrm{mL}$ showed statistical difference, in relation to the control, for the mortality percentage of evaluated caterpillars (Fig. 1a).

The average mortality of $A$. gemmatalis and $S$. frugiperda in trials with ethyl acetate extract ranged from $6.6 \%$ to $90.0 \%$. The highest concentration, 15 $\mathrm{mg} / \mathrm{mL}$, induced $90.0 \%$ mortality for $A$. gemmatalis and $43.3 \%$ for $S$. frugiperda (Fig. 1b).

The ethanol extract of $P$. aduncum induced $23.3 \%$ mortality of A. gemmatalis and $26.6 \%$ mortality of $S$. frugiperda, for the highest concentration evaluated $(15 \mathrm{mg} / \mathrm{mL})$, with no statistically significant difference compared to other concentrations and the control group for both insect species (Fig. 1c).

Hexane and ethyl acetate extracts of $P$. aduncum induced the highest mortality rates of $A$. gemmatalis and $S$. frugiperda. These results can be attributed to the higher concentrations of phenylpropanoid in these extracts. These compounds derived from phenylalanine are present in most plant of the Piperaceae family. Several authors have found that these plant species have insecticidal and acaricidal activity (Salgado et al. 2012, Souto et al. 2012, Trindade et al. 2012, Lima et al. 2014, Santana et al. 2015).
Apiol was the major compound (90.7\%) identified in the hexane and ethyl acetate extracts (54.9\%). Santana et al. (2015) found that apiol was one of two major constituents of the $P$. aduncum essential oil and attributed larvicidal activity on the dengue vector $A$. aegypti (Diptera) to apiol. Khalaf (2004) confirmed the biological activity of apiol, because it interfered with growth and reduced fertility of adult flies of the species Parasarcophaga dux (Diptera). Studies with essential oil of Petroselinum crispum fruit, whose two main compounds were apiol and myristicin, demonstrated its high effectiveness in inhibiting oviposition of Pseudaletia unipuncta (Sousa et al. 2015).

The insecticidal activity of hexane and ethyl acetate extracts of $P$. aduncum may be associated with synergistic action of the phenylpropanoids apiol and myristicin, by inhibiting the function of cytochrome P450. According to Wilkinson et al. (1984), the secondary metabolites ingested by the insect form a complex with major detoxification enzymes, of dependent monooxygenase of cytochrome P450. According to Berenbaum (2002), these enzymes participate in many manufacturing processes in insects, which include ecdysteroid and juvenile hormone biosynthesis as well as detoxification from plant compounds and insecticides. Bernard and Philogene (1993) and Hodgson et al. (1995) argue that the synergists compounds bind to $\mathrm{P} 450$, inactivating this enzyme, which impedes metabolization of insecticide molecules. Li et al. (2007) report that inhibiting monooxygenase reduces the ability of the herbivorous insect to excrete xenobiotics, which results in mortality due to the accumulation of toxic substances in their digestive tract.

In addition, the insecticidal effect of these phenylpropanoid may be due to collaboration with other minor bioactive compounds, such as $\beta$-caryophyllene and $\beta$-selinene sesquiterpenes present in the hexane extract. According to Veiga 

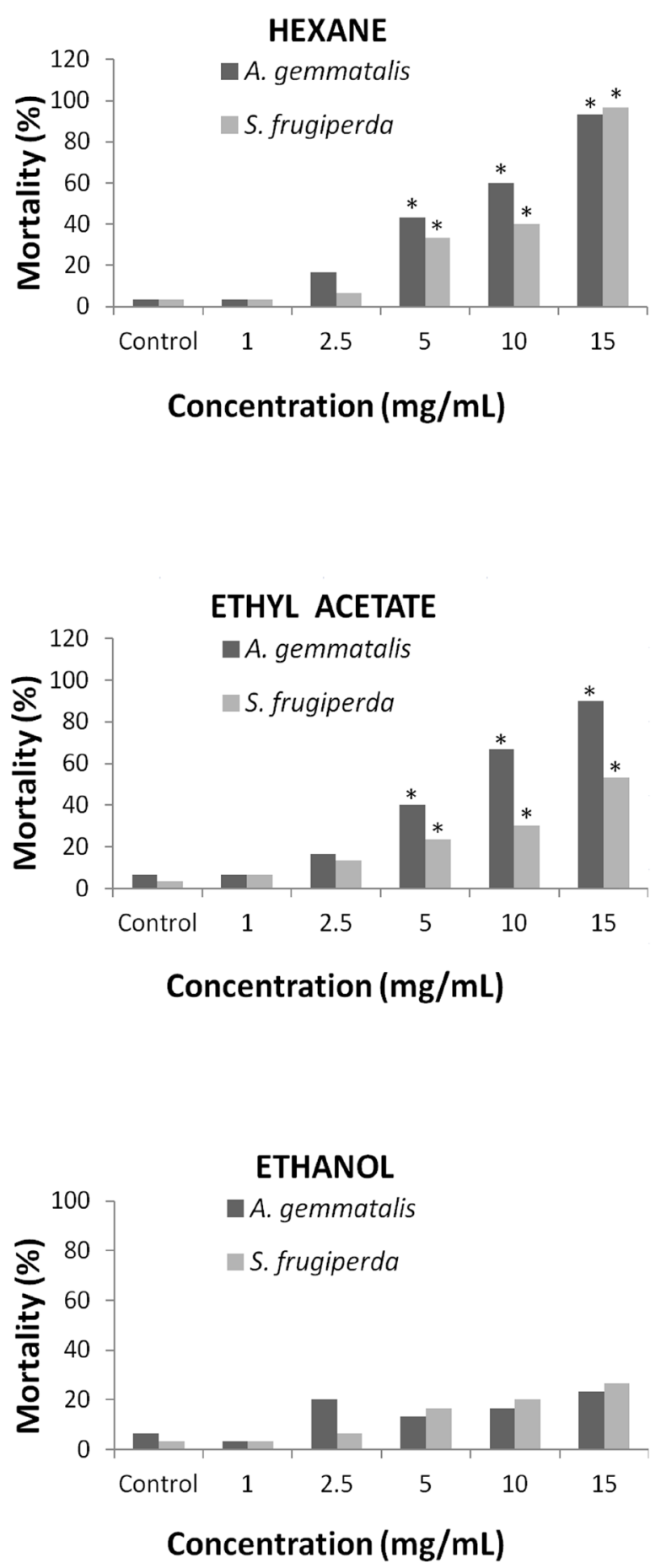

Figure 1 - Cumulative mortality of Anticarsia gemmatalis and Spodoptera frugiperda fed with artificial diet containing: a) hexane, b) ethyl acetate, and c) ethanol extracts of Piper aduncum leaves. *Averages mortality differs in relation to control as determined by Tukey test $(\mathrm{p} \leq 0.05)$.
Junior et al. (2005), $\beta$-caryophyllene is described in the literature to contain bactericide and insect repelling properties. Costantin et al. (2001) identified $\beta$-caryophyllene, $\alpha$ and $\beta$-pinene, bicyclogermacrene, spathulenol, and germacrene-D in Piper cernuum with antimicrobial activity. Other authors observed that the $\beta$-caryophyllene inhibits growth of the parasite Trypanosoma cruzi and Leishmania brasiliensis (Leite et al. 2013).

The mortality of A. gemmatalis and $S$. frugiperda, when compared to each other in the studied concentrations, presented statistical difference only in trials with ethyl acetate extract at concentration of $10 \mathrm{mg} / \mathrm{mL}$. This may be related to the fact that $S$. frugiperda is polyphagous and therefore more resistant, which prevented mortality greater than $50 \%$ of this insect. Fortunato et al. (2007) stated that polyphagous insects, such as S. frugiperda, have a wide variety of digestive enzymes, due to the diverse chemical composition in their diet. Thus, polyphagous insects can best metabolize the compounds of their diet when compared to non-polyphagous insects, such as $A$. gemmatalis.

In relation to the estimated values of the median lethal concentration $\left(\mathrm{LC}_{50}\right)$ for $A$. gemmatalis, the hexane and ethyl acetate extracts presented the same toxicity. The hexane extract had the same efficacy of potential toxicity for both lepidopteran larvae. In tests with ethanol extract against $A$. gemmatalis and ethyl acetate and ethanol extract against $S$. frugiperda, the mortality percentages were lower than $50 \%$, which prevented calculation of $\mathrm{LC}_{50}$ (Table II).

During the larval period, A. gemmatalis was fed a diet containing hexane extract of $P$. aduncum leaves, with increasing concentrations of extract. Statistical differences were observed between the control group and $5.0 \mathrm{mg} / \mathrm{mL}$ concentration. The duration of the pupal stage increased by approximately one day for the $2.5 \mathrm{mg} / \mathrm{mL}$ concentration. No statistical differences were found 
TABLE II

Median Lethal Concentration $\left(\mathrm{LC}_{50}\right)$ of hexane, ethyl acetate, and ethanol extracts of Piper aduncum against Anticarsia gemmatalis and Spodoptera frugiperda.

Insect $\quad$ Extract $\quad \mathrm{LC}_{50} \quad$ Confidence $(\mathrm{mg} / \mathrm{mL}) \quad$ Interval

A.

Hexane $\quad 6.35^{\text {ab }} \quad 4.82-7.98$

gemmatalis

Ethyl acetate $\quad 5.79^{\text {a }} \quad 4.57-7.39$

Average mortality followed by different letters differs by Tukey test $(\mathrm{p} \leq 0.05)$.

TABLE III

Biological parameters of Anticarsia gemmatalis and Spodoptera frugiperda fed artificial diet containing the hexane extract of Piper aduncum leaves.

\begin{tabular}{|c|c|c|c|c|c|c|}
\hline \multicolumn{7}{|c|}{ Anticarsia gemmatalis } \\
\hline Biological parameters & Control & $1 \mathrm{mg} / \mathrm{mL}$ & $2.5 \mathrm{mg} / \mathrm{mL}$ & $5 \mathrm{mg} / \mathrm{mL}$ & $10 \mathrm{mg} / \mathrm{mL}$ & $15 \mathrm{mg} / \mathrm{mL}$ \\
\hline $\mathrm{n}$ & 29 & 29 & 25 & 17 & 12 & 2 \\
\hline Larval duration (days) & $8.9 \pm 1.87 \mathrm{a}$ & $9.2 \pm 1.75 \mathrm{ab}$ & $9.8 \pm 1.75 \mathrm{ab}$ & $10.3 \pm 2.47 \mathrm{bc}$ & $11.8 \pm 2.30 \mathrm{c}$ & $11.5 \pm 0.5 \mathrm{c}$ \\
\hline Pupal duration (days) & $9.9 \pm 1.24 \mathrm{a}$ & $10.6 \pm 1.20 \mathrm{ab}$ & $11.3 \pm 1.68 \mathrm{~b}$ & $11.4 \pm 1.61 \mathrm{~b}$ & $11.7 \pm 1.22 .0 \mathrm{~b}$ & $11.5 \pm 1.34 \mathrm{~b}$ \\
\hline Pupal weight (mg) & $0.2 \pm 0.02 \mathrm{a}$ & $0.2 \pm 0.02 \mathrm{a}$ & $0.2 \pm 0.02 \mathrm{a}$ & $0.2 \pm 0.01 \mathrm{a}$ & $0.2 \pm 0.01 \mathrm{a}$ & $0.2 \pm 0.002 \mathrm{a}$ \\
\hline Pupal width (mm) & $5.2 \pm 0.22 \mathrm{a}$ & $4.9 \pm 0.35 \mathrm{a}$ & $5.0 \pm 0.24 \mathrm{a}$ & $5.1 \pm 0.20 \mathrm{a}$ & $5.0 \pm 0.32 \mathrm{a}$ & $4.8 \pm 0.32 \mathrm{a}$ \\
\hline Pupal length (mm) & $18.1 \pm 0.59 \mathrm{a}$ & $17.9 \pm 0.78 \mathrm{ab}$ & $17.7 \pm 0.72 \mathrm{ab}$ & $17.6 \pm 0.65 \mathrm{ab}$ & $17.3 \pm 0.67 \mathrm{ab}$ & $16.9 \pm 0.53 \mathrm{~b}$ \\
\hline \multicolumn{7}{|c|}{ Spodoptera frugiperda } \\
\hline Biological parameters & Control & $1 \mathrm{mg} / \mathrm{mL}$ & $2.5 \mathrm{mg} / \mathrm{mL}$ & $5 \mathrm{mg} / \mathrm{mL}$ & $10 \mathrm{mg} / \mathrm{mL}$ & $15 \mathrm{mg} / \mathrm{mL}$ \\
\hline $\mathrm{n}$ & 29 & 29 & 28 & 20 & 18 & 1 \\
\hline Larval duration & $19.8 \pm 1.34 \mathrm{a}$ & $21.5 \pm 1.36 \mathrm{~b}$ & $22.8 \pm 1.25 \mathrm{bc}$ & $23.4 \pm 1.29 \mathrm{c}$ & $23.5 \pm 1.46 \mathrm{c}$ & - \\
\hline Pupal duration (days) & $11.4 \pm 1.27 \mathrm{a}$ & $12.1 \pm 1.28 \mathrm{ab}$ & $13.2 \pm 1.34 \mathrm{bc}$ & $13.4 \pm 1.51 \mathrm{c}$ & $13.5 \pm 1.46 \mathrm{c}$ & - \\
\hline Pupal weight (mg) & $0.2 \pm 0.02 \mathrm{a}$ & $0.2 \pm 0.02 \mathrm{a}$ & $0.2 \pm 0.01 \mathrm{a}$ & $0.2 \pm 0.02 \mathrm{a}$ & $0.2 \pm 0.39 \mathrm{a}$ & - \\
\hline Pupal width (mm) & $4.8 \pm 0.30 \mathrm{a}$ & $4.6 \pm 0.49 \mathrm{a}$ & $4.6 \pm 0.34 \mathrm{a}$ & $4.7 \pm 0.42 \mathrm{a}$ & $4.7 \pm 0.39 \mathrm{a}$ & - \\
\hline Pupal length (mm) & $15.8 \pm 1.05 \mathrm{a}$ & $15.0 \pm 0.76 \mathrm{a}$ & $15.3 \pm 0.85 \mathrm{a}$ & $15.4 \pm 1.07 \mathrm{a}$ & $15.6 \pm 1.28 \mathrm{a}$ & - \\
\hline
\end{tabular}

For means followed by the same letters, the lines do not differ by Tukey test $(\mathrm{p} \leq 0.05)$. 
TABLE IV

Biological parameters of Anticarsia gemmatalis and Spodoptera frugiperda fed artificial diet containing the ethyl acetate extract of Piper aduncum leaves.

\begin{tabular}{|c|c|c|c|c|c|c|}
\hline \multicolumn{7}{|c|}{ Anticarsia gemmatalis } \\
\hline Biological parameters & Control & $1 \mathrm{mg} / \mathrm{mL}$ & $2.5 \mathrm{mg} / \mathrm{mL}$ & $5 \mathrm{mg} / \mathrm{mL}$ & $10 \mathrm{mg} / \mathrm{mL}$ & $15 \mathrm{mg} / \mathrm{mL}$ \\
\hline $\mathrm{n}$ & 28 & 28 & 25 & 18 & 10 & 3 \\
\hline Larval duration (days) & $14.1 \pm 1.30 \mathrm{a}$ & $14.7 \pm 1.34 \mathrm{a}$ & $15.4 \pm 1.20 \mathrm{ab}$ & $16.2 \pm 1.22 \mathrm{~b}$ & $17.3 \pm 1.46 \mathrm{~b}$ & $17.8 \pm 1.45 \mathrm{~b}$ \\
\hline Pupal duration (days) & $9.2 \pm 1.25 \mathrm{a}$ & $10.1 \pm 1.27 \mathrm{ab}$ & $10.1 \pm 1.34 \mathrm{ab}$ & $11.3 \pm 1.31 \mathrm{~b}$ & $13.1 \pm 1.21 \mathrm{c}$ & $13.2 \pm 1.23 \mathrm{c}$ \\
\hline Pupal weight (mg) & $0.3 \pm 0.03 \mathrm{a}$ & $0.2 \pm 0.03 \mathrm{~b}$ & $0.2 \pm 0.03 \mathrm{~b}$ & $0.2 \pm 0.03 \mathrm{~b}$ & $0.2 \pm 0.03 \mathrm{~b}$ & $0.2 \pm 0.03 \mathrm{~b}$ \\
\hline Pupal width (mm) & $5.9 \pm 0.31 \mathrm{a}$ & $5.3 \pm 0.36 \mathrm{a}$ & $5.2 \pm 0.39 \mathrm{a}$ & $5.2 \pm 0.34 \mathrm{a}$ & $4.9 \pm 0.49 \mathrm{a}$ & $5.8 \pm 0.36 \mathrm{a}$ \\
\hline Pupal length (mm) & $19.0 \pm 1.00 \mathrm{a}$ & $17.7 \pm 0.88 \mathrm{a}$ & $17.6 \pm 1.01 \mathrm{a}$ & $17.1 \pm 1.27 \mathrm{a}$ & $17.5 \pm 0.94 \mathrm{a}$ & $18.8 \pm 0.26 \mathrm{a}$ \\
\hline \multicolumn{7}{|c|}{ Spodoptera frugiperda } \\
\hline Biological parameters & Control & $1 \mathrm{mg} / \mathrm{mL}$ & $2.5 \mathrm{mg} / \mathrm{mL}$ & $5 \mathrm{mg} / \mathrm{mL}$ & $10 \mathrm{mg} / \mathrm{mL}$ & $15 \mathrm{mg} / \mathrm{mL}$ \\
\hline $\mathrm{n}$ & 29 & 28 & 26 & 23 & 21 & 16 \\
\hline Larval duration (days) & $19.8 \pm 1.26 \mathrm{a}$ & $18.1 \pm 1.32 \mathrm{a}$ & $18.6 \pm 1.29 \mathrm{a}$ & $19.3 \pm 1.34 \mathrm{a}$ & $19.5 \pm 1.38 \mathrm{a}$ & $21.3 \pm 1.35 \mathrm{~b}$ \\
\hline Pupal duration (days) & $11.4 \pm 1.37 \mathrm{a}$ & $11.5 \pm 1.39 \mathrm{a}$ & $11.5 \pm 1.29 \mathrm{a}$ & $11.6 \pm 1.34 \mathrm{a}$ & $11.6 \pm 1.37 \mathrm{a}$ & $11.7 \pm 1.39 \mathrm{a}$ \\
\hline Pupal weight (mg) & $0.2 \pm 0.16 \mathrm{a}$ & $0.2 \pm 0.02 \mathrm{a}$ & $0.2 \pm 0.24 \mathrm{a}$ & $0.2 \pm 0.03 \mathrm{a}$ & $0.2 \pm 0.02 \mathrm{a}$ & $0.2 \pm 0.03 \mathrm{a}$ \\
\hline Pupal width (mm) & $4.8 \pm 0.30 \mathrm{a}$ & $4.8 \pm 0.34 \mathrm{a}$ & $4.5 \pm 0.41 \mathrm{a}$ & $4.4 \pm 0.52 \mathrm{a}$ & $4.4 \pm 0.51 \mathrm{a}$ & $4.3 \pm 0.62 \mathrm{a}$ \\
\hline Pupal length (mm) & $15.8 \pm 1.05 \mathrm{a}$ & $15.7 \pm 1.07 \mathrm{a}$ & $16.0 \pm 1.23 \mathrm{a}$ & $16.5 \pm 0.81 \mathrm{a}$ & $16.2 \pm 1.08 \mathrm{a}$ & $15.7 \pm 0.91 \mathrm{a}$ \\
\hline
\end{tabular}

For means followed by the same letters, the lines do not differ by Tukey test $(\mathrm{p} \leq 0.05)$.

$96.6 \%$ mortality was obtained of larvae during the first five days, which made it impossible to analyze the biological parameters (Table III).

For the ethyl acetate extract of $P$. aduncum leaves, assays with $A$. gemmatalis found extended larval and pupal stages due to the $5.0 \mathrm{mg} / \mathrm{ml}$ concentration, compared to control. Pupal weight reduced at all concentrations of the extract. However, for width and length, the control group and studied concentrations presented no statistical difference (Table IV).

The larval period of S. frugiperda was prolonged by 1.8 days by the $15.0 \mathrm{mg} / \mathrm{mL}$ concentration of the ethyl acetate extract compared to the control group. The duration of the pupal period showed no statistical difference for treatment in all evaluated concentrations. However, the pupal weight showed no statistical difference between the treatments and the control group. The width and length of the pupae did not statistically differ between treatments (Table IV).

For the ethanol extract of $P$. aduncum leaves, the larval period of A. gemmatalis ranged from 17.9 to 19.8 days, and it was extended significantly with $2.5 \mathrm{mg} / \mathrm{mL}$ concentration compared to control. The duration of the pupal stage ranged from 15.2 to 18.1 days and increased beginning with $1.0 \mathrm{mg} / \mathrm{mL}$ concentration. The pupae presented reduced weight in all treatments compared to the control. The width and length showed no statistical difference between the control and the concentrations evaluated in the treatments (Table V).

The ethanol extract extended the duration of larval and pupal periods of $S$. frugiperda beginning 
TABLE V

Biological parameters of Anticarsia gemmatalis and Spodoptera frugiperda fed artificial diet containing the ethanol extract of Piper aduncum leaves.

\begin{tabular}{|c|c|c|c|c|c|c|}
\hline \multicolumn{7}{|c|}{ Anticarsia gemmatalis } \\
\hline Biological parameters & Control & $1 \mathrm{mg} / \mathrm{mL}$ & $2.5 \mathrm{mg} / \mathrm{mL}$ & $5 \mathrm{mg} / \mathrm{mL}$ & $10 \mathrm{mg} / \mathrm{mL}$ & $15 \mathrm{mg} / \mathrm{mL}$ \\
\hline $\mathrm{n}$ & 28 & 29 & 26 & 26 & 25 & 23 \\
\hline Larval duration (days) & $16.4 \pm 1.24 \mathrm{a}$ & $\begin{array}{c}17.9 \pm 1.29 \\
\mathrm{ab}\end{array}$ & $18.5 \pm 1.25 \mathrm{bc}$ & $18.2 \pm 1.24 \mathrm{bc}$ & $\begin{array}{c}18.7 \pm 1.33 \\
\text { bc }\end{array}$ & $19.8 \pm 1.37 \mathrm{c}$ \\
\hline Pupal duration (days) & $13.3 \pm 1.32 \mathrm{a}$ & $15.2 \pm 1.35 \mathrm{~b}$ & $16.2 \pm 1.35 \mathrm{bc}$ & $16.4 \pm 1.39 \mathrm{bc}$ & $17.2 \pm 1.45 \mathrm{c}$ & $18.1 \pm 1.43 \mathrm{~d}$ \\
\hline Pupal weight (mg) & $0.3 \pm 0.02 \mathrm{a}$ & $0.2 \pm 0.03 \mathrm{~b}$ & $0.2 \pm 0.02 \mathrm{~b}$ & $0.2 \pm 0.02 \mathrm{~b}$ & $0.2 \pm 0.02 \mathrm{~b}$ & $0.2 \pm 0.01 \mathrm{~b}$ \\
\hline Pupal width (mm) & $5.8 \pm 0.58 \mathrm{a}$ & $5.3 \pm 0.46 \mathrm{a}$ & $5.4 \pm 0.31 \mathrm{a}$ & $5.2 \pm 0.20 \mathrm{a}$ & $5.4 \pm 0.37 \mathrm{a}$ & $5.4 \pm 0.40 \mathrm{a}$ \\
\hline Pupal length (mm) & $18.7 \pm 0.74 \mathrm{a}$ & $17.2 \pm 1.48 \mathrm{a}$ & $17.4 \pm 0.57 \mathrm{a}$ & $17.9 \pm 0.81 \mathrm{a}$ & $17.8 \pm 0.87 \mathrm{a}$ & $17.6 \pm 0.62 \mathrm{a}$ \\
\hline \multicolumn{7}{|c|}{ Spodoptera frugiperda } \\
\hline Biological parameters & Control & $1 \mathrm{mg} / \mathrm{mL}$ & $2.5 \mathrm{mg} / \mathrm{mL}$ & $5 \mathrm{mg} / \mathrm{mL}$ & $10 \mathrm{mg} / \mathrm{mL}$ & $15 \mathrm{mg} / \mathrm{mL}$ \\
\hline $\mathrm{n}$ & 30 & 29 & 28 & 25 & 24 & 22 \\
\hline Larval duration (days) & $14.9 \pm 1.31 \mathrm{a}$ & $18.6 \pm 1.34 \mathrm{~b}$ & $19.2 \pm 1.29 \mathrm{~b}$ & $21.3 \pm 1.35 \mathrm{c}$ & $21.3 \pm 1.39 \mathrm{c}$ & $21.5 \pm 1.41 \mathrm{c}$ \\
\hline Pupal duration (days) & $11.2 \pm 1.25 \mathrm{a}$ & $13.3 \pm 1.29 \mathrm{~b}$ & $13.5 \pm 1.32 \mathrm{~b}$ & $13.5 \pm 1.29 \mathrm{~b}$ & $13.6 \pm 1.32 \mathrm{~b}$ & $13.6 \pm 1.34 \mathrm{~b}$ \\
\hline Pupal weight (mg) & $0.2 \pm 0.02 \mathrm{a}$ & $0.2 \pm 0.2 \mathrm{a}$ & $0.2 \pm 0.02 \mathrm{a}$ & $0.2 \pm 0.33 \mathrm{a}$ & $0.2 \pm 0.02 \mathrm{a}$ & $0.2 \pm 0.02 \mathrm{a}$ \\
\hline Pupal width (mm) & $4.8 \pm 0.24 \mathrm{a}$ & $4.6 \pm 0.33 \mathrm{a}$ & $4.6 \pm 0.43 \mathrm{a}$ & $4.8 \pm 0.49 \mathrm{a}$ & $4.5 \pm 0.54 \mathrm{a}$ & $3.9 \pm 0.71 \mathrm{a}$ \\
\hline Pupal length (mm) & $16.6 \pm 0.79 \mathrm{a}$ & $16.0 \pm 0.86 \mathrm{a}$ & $16.1 \pm 1.03 \mathrm{a}$ & $16.1 \pm 0.85 \mathrm{a}$ & $16.1 \pm 0.96 \mathrm{a}$ & $15.8 \pm 1.04 \mathrm{a}$ \\
\hline
\end{tabular}

For means followed by the same letters, the lines do not differ by Tukey test $(\mathrm{p} \leq 0.05)$.

at $1.0 \mathrm{mg} / \mathrm{mL}$ concentration compared to control. The pupal weight did not statistically change between the treatments and the control group. No statistically significant differences appeared in the width and length of the pupae in the control group and the studied concentrations (Table V).

The extension of the larval and pupal stages by different extracts can be attributed to the presence of growth inhibitors or toxic substances (phenylpropanoid and sesquiterpenes) in the extracts. Studies have shown that organic compounds in plants with insecticidal activity can act as chitin synthesis inhibitors and may affect growth, development, reproduction, and diapause in insects (Aguiar-Menezes 2005). Phenylpropanoids are toxic to insects and may affect the life cycle of insects (Regnault-Roger et al. 2012, Kim and Lee 2014). Studies using leaf extracts from $A$. coriacea and $A$. dioica, with high content of phenolic compounds, found decreased weight gain, adult emergence, fecundity, fertility, and egg hatching of S. frugiperda (Freitas et al. 2014).

Morphological and physiological changes observed in this study may be attributed to the action of phenylpropanoid and sesquiterpenes, which can cause toxic interference in biochemical and physiological functions of insects. According to Trindade et al. (2000), some components of the extract interfere with the hormonal system that regulates insect larval development. Mordue and Blackwell (1993) argue that these changes result from reduced concentration of ecdysone or delay 
of its release in the hemolymph, which affects larval development, thereby reducing the insect population and damage to plants.

Other researchers have found similar results in the duration of $S$. frugiperda larva as induced by the hexane extract of $P$. aduncum (Table III). Santiago et al. (2008) observed this with aqueous extracts of Ruta graveolens (26 days), Momordica charantia (22.6 days), and Lippia sidoides (24.8 days). Knaak et al. (2012) used aqueous extracts obtained by maceration and infusion of the species Symphitum officinalis (26.9 days), Zingiber officinale (28.6 days), and Melissa officinalis (26.6 days). However, the larvae treated with plant extracts in the studies of these authors showed no significant difference from the control group, unlike the hexane extract evaluated in our study. Under field conditions, extending the larval stage can increase the exposure time to the plague of natural enemies and reduce the number of generations (Torres et al. 2001). These factors are important for maize production, because this Lepidoptera can cause yield losses up to $54.5 \%$ (Figueiredo et al. 2006), depending on climactic conditions and development stage in which the plant is attacked (Dequech et al. 2013, Ribeiro et al. 2014).

With respect to the morphometric parameters (weight, length, and width), the larvae fed with diet containing extract produced smaller pupae and adults than the control group. Some authors have attributed this effect to the presence of peptidase inhibitors, which can be expressed by plants as a defense mechanism (Gahloth et al. 2011, Macedo et al. 2011, Cruz et al. 2013, Ghodke et al. 2013) resulting in delayed development of insects.

Lepidoptera accumulate reserves during larval development, and the adverse conditions in the process cause asynchrony with normal population which leads to problems with these insects' reproduction (Rodriguez and Vendramim 1997, Matos et al. 2006), fertility, and low performance of their offspring (Fantinou et al. 2008).
Based on these results, we conclude that the hexane and ethyl acetate extracts of $P$. aduncum have biological activity on $A$. gemmatalis and $S$. frugiperda species. Future studies with compounds isolated from these extracts may contribute to management strategies for these insect pests. The detection of new sources of insecticidal compounds from flora remains one of the principal gaps to be filled.

\section{ACKNOWLEDGMENTS}

The authors wish to thank the Conselho Nacional de Desenvolvimento Científico e Tecnológico (CNPq), Coordenação de Aperfeiçoamento de Pessoal de Ensino Superior (CAPES), and Fundação de Amparo à Pesquisa do Estado do Amazonas (FAPEAM) for their financial support. We also thank Alene Alder-Rangel for assistance with the english in the manuscript.

\section{REFERENCES}

ABREU OA, SÁNCHEZ I, PINO J AND BARRETO G. 2015. Antimicrobial activity of Piper aduncum sub sp Ossanum essential oil. Int J Phytomed 7: 205-208.

AGUIAR-MENEZES ELM. 2005. Inseticidas botânicos: seus princípios ativos, modo de ação e uso agrícola. Embrapa Agrobiologia, Documentos 205, 58 p.

ALMEIDA RRP, SOUTO RNP, SILVA MHL AND MAIA JGS. 2009. Chemical variation in Piper aduncum and biological properties of its dillapiole-rich essential oil. Chem Biodiversity 9: 1427-1434.

ARROYO-ACEVEDO J, CHÁVEZ-ASMAT RJ, ANAMPAGUZMÁN A, DONAIRES R AND RÁEZ-GONZÁLES J. 2015. Protective effect of Piper aduncum capsule on DMBA- induced breast cancer in rats. Breast Cancer: Basic Clin Res 9: 41-48.

BARROS FJ, COSTA RJO, CESÁRIO FRAS, RODRIGUES LB, COSTA JGM, COUTINHO HDM, GALVÃO HBF AND DE MENEZES IRA. 2016. Activity of essential oils of Piper aduncum and Cinnamomum zeylanicum by evaluating osmotic and morphologic fragility of erythrocytes. Eur J Integr Med 8: 505-512.

BERENBAUM MR. 2002. Postegenomic chemical ecology: From genetic code to ecological interactions. J Chem Ecol 28: 873-896. 
BERNARD CB AND PHILOGENE BJ. 1993. Insecticide synergists: role, importance and perspectives. J Toxicol Environ Health 38: 199-223.

CARMONA-HERNÁNDEZ O, FERNÁNDEZ MS, PALMEROS-SÁNCHEZ B AND LOZADA-GARCÍA JA. 2014. Actividad insecticida de extractos etanólicos foliares de nueve piperáceas (Piper spp.) en Drosophila melanogaster. Rev Int Contam Ambie 30: 67-73.

COSTANTIN MB, SARTORELLI P, LIMBERGER R, HENRIQUES AT, STEPPE M, FERREIRA MJP, OHARA MT, EMERENCIANO VP AND KATO MJ. 2001. Essential oils from Piper cernuum and Piper regnelliAntimicrobial activities and analyses by GC/MS and C13 NMR. Planta Med 67: 771-773.

CRUZ ACB ET AL. 2013. Bioinsecticidal activity of a novel Kunitz trypsin inhibitor from catanduva (Piptadenia moniliformis) seeds. Plant Physiol Biochem 70: 61-68.

CRUZ GS, WANDERLEY-TEIXEIRA V, OLIVEIRA JV, CORREIA AA, BREDA MO, ALVES TJS, CUNHA FM, TEIXEIRA AAC, DUTRA KA AND NAVARRO DMAF. 2014. Bioactivity of Piper hispidinervum (Piperales: Piperaceae) and Syzygium aromaticum (Myrtales: Myrtaceae) Oils, with or without Formulated Bta on the Biology and Immunology of Spodoptera frugiperda (Lepidoptera: Noctuidae). J Econ Entomol 107(1): 144153.

DEQUECH STB, CAMERA C, STURZA VS, RIBEIRO LP, QUERINO RB AND PONCIO S. 2013. Population fluctuation of Spodoptera frugiperda eggs and natural parasitism by Trichogramma in maize. Acta Sci Agron 35: 295-300.

FANTINOU AA, PERDIKS DC AND STAMOGIANIS N. 2008. Effect of larval crowding on the life history traits of Sesamia nonagrioides (Lepidoptera: Noctuidae). Eur J Entomol 105: 625-630.

FAZOLIN M, ESTRELA JLV, CATANI V and COSTA CR. 2006. Potencialidades da pimenta-de-macaco (Piper aduncum L.): características gerais e resultados de pesquisa. Embrapa Documentos 103, 53 p.

FIGUEIREDO MLC, MARTINS-DIAS AMP AND CRUZ I. 2006. Relação entre a lagarta-do-cartucho e seus agentes de controle biológico natural na produção de milho. Pesqui Agropecu Bras 41: 1693-1698.

FINNEY DJ .1971. Probit analysis. $3^{\text {rd }}$ ed., London: Cambridge University Press, $25 \mathrm{p}$.

FORTUNATO FS, OLIVEIRA MGA, BRUMANO MHN, SILVA CHO, GUEDES RNC AND MOREIRA MA. 2007. Lipoxygenase-induced defence of soybean varieties to the attack of the velvetbean caterpillar (Anticarsia gemmatalis Hübner). J Pestic Sci 80: 241-247.

FREITAS AF, PEREIRAFF, FORMAGIOASN, LUCCHETTA JT, VIEIRA MC AND MUSSURY RM. 2014. Effects of methanolic extracts of Annona species on the development and reproduction of Spodoptera frugiperda (J.E. Smith) (Lepidoptera: Noctuidae). Neotrop Entomol 43: 446-452.

GAHLOTH D, SHUKLA U, BIRAH A, GUPTA GP, KUMAR PA, DHALIWAL HS AND SHARMA AK. 2011. Bioinsecticidal activity of Murraya koenigii miraculinlike protein against Helicoverpa armigera and Spodoptera litura. Arch Insect Biochem Physiol 78: 132-144.

GHODKE AB, CHAVAN SG, SONAWANE BV AND BHAROSE AA. 2013. Isolation and in vitro identification of proteinase inhibitors from soybean seeds inhibiting Helicoverpa gut proteases. J Plant Interact 8: 170-178.

GREENE GL, LEPPLA NC AND DICKERSON WA. 1976. Velvetbean caterpillar: a rearing procedure and artificial medium. J Econ Entomol 69: 487-488.

HODGSON E, RYU D, ADAMS N AND LEVIET PE. 1995. Biphasic responses in synergistic interactions. Toxicol 105: 211-216.

KHALAF AF. 2004. Toxicological efficacy of some indigenous dill compounds against the flesh fly, Parasarcophaga $d u x$ Thomson. J Egypt Soc Parasitol 34: 227-237.

KIM SI AND LEE DW. 2014. Toxicity of basil and orange essential oils and their components against two coleopteran stored products insect pests. J Asia-Pac Entomol 17: 13-17.

KNAAK N, TAGLIARI MS, MACHADO V AND FIUZA LM. 2012. Atividade Inseticida de Extratos de plantas medicinais Sobre Spodoptera frugiperda (J.E. Smith) (Lepidoptera: Noctuidae). BioAssay 7: 1-6.

LEITE NF ET AL. 2013. Atividade antiparasitária in vitro e citotóxica de cariofileno e eugenol contra Trypanossoma cruzi e Leishmania brasiliensis. Rev Cubana Plant Med 18(4): 522-528.

LI X, SCHULER MA AND BERENBAUM MR. 2007. Molecular mechanisms of metabolic resistance to synthetic and natural xenobiotics. Annu Rev Entomol 52: 231-253.

LIMA ADAS, SOUSA FILHO JG, PEREIRA SG, GUILLON GM, SANTOS LS AND COSTA JÚNIOR LM. 2014. Acaricide activity of different extracts from Piper tuberculatum fruits against Rhipicephalus microplus. Parasitol Res 113: 107-112.

MACEDO MLR, FREIRE MGM, FRANCO OL, MIGLIOLO L AND OLIVEIRA CFR. 2011. Practical and theoretical characterization of Inga laurina Kunitz inhibitor on the control of Homalinotus coriaceus. Comp Biochem Physiol Part B: Biochem Mol Biol 158: 164-172.

MATOS AP, NEBO L, CALEGARI ER, BATISTA-PEREIRA LG, VIEIRA PC, FERNANDES JB, SILVA MFGF, FILHO PF AND RODRIGUES RR. 2006. Atividades biológicas de extratos orgânicos de Trichilia spp. (Meliaceae) sobre Spodoptera frugiperda (J.E. Smith) (Lepidoptera:Noctuidae) em dieta artificial. BioAssay 1: 1-7.

MISNI N, SALAIMAN S AND OTHMAN H. 2008. The repellent activity of Piper aduncum Linn (Family: 
Piperaceae) essential oil against Aedes aegypti using human volunteers. J Trop Med Parasitol 31: 63-69.

MORANDIM ADA, KATO MJ, CAVALHEIRO AJ AND FURLAN M. 2009. Intraspecific variability of dihydrochalcone, chromenes and benzoic acid derivatives in leaves of Piper aduncum L. (Piperaceae). Afr J Biotechnol 8: 2157-2162.

MORDUE AJ AND BLACKWELL A. 1993. Azadirachtin: an update. J Insect Physiol 39: 903-924.

NIST. 2016. Mass Spectral Library with Search Program (Data Version: NIST 11, Software Version 2.0g) [(accessed on 16 April 2016)]. Available online: http://www.nist.gov/srd/ nist1a.cfm\#/.

REGNAULT-ROGER C, VINCENT C AND ARNASON JT. 2012. Essential oils in insect control: low-risk products in a high-stakes world. Annu Rev Entomol 57: 405-424.

RIBEIRO LP, DEQUECH S TB, CAMERA C, STURZA VS, PONCIO S AND VENDRAMIM JD. 2014. Vertical and temporal distribution of Spodoptera frugiperda (JE Smith) (Lepidoptera: Noctuidae) egg masses, parasitized and nonparasitized, on maize plants. Maydica 59: 315-320.

RIVA D, SIMIONATTO EL, WISNIEWSKI A, SALERNO AR AND SCHALLENBERGER TH. 2011. Estudo da adaptação da espécie Piper hispidinervum C. DC. (pimenta longa) à região do Vale do Itajaí - SC, através da composição química do óleo essencial obtido por hidrodestilação por micro-ondas e convencional. Acta Amazonica 41: 297-302.

RODRÍGUEZ HC AND VENDRAMIM JD. 1997. Avaliação da bioatividade de extratos aquosos de Meliaceae sobre Spodoptera frugiperda (J. E. Smith). Ver Agric (Piracicaba, Braz.) 72: 305-318.

SALGADO DN, FARONI LRD AND SOTO A. 2012. Aceite essencial de Piper crassinervum para el control de Sitophilus zeamais (Coleoptera: Curculionidae). Bol Cient Mus His Nat 16: 99-107.

SANTANA HT, TRINDADE FTT, STABELI RG, SILVA AAE, MILITÃO JSTL AND FACUNDO VA. 2015. Essential oils of leaves of Piper species display larvicidal activity against the dengue vector, Aedes aegypti (Diptera: Culicidae). Rev Bras Plant Med 17: 105-111.

SANTIAGO GP, PÁDUA LEM, SILVA PRR, CARVALHO SEM AND MAIA CB. 2008. Efeitos de extratos de plantas na biologia de Spodoptera frugiperda (J. E. Smith 1797) (Lepidoptera: Noctuidae) mantida em dieta artificial. Cienc Agrotecnol 32: 792-796.

SILVA AL, CHAVES FCM, LAMEIRA RC AND BIZZO HR. 2013. Rendimento e composição do óleo essencial de Piper aduncum L. cultivado em Manaus, AM, em função da densidade de plantas e épocas de corte. Rev Bras Plant Med 15: 670-674.

SILVA WC, MARTINS JRS, SOUZA HEM, HEINZEN H, CESIO MV, MATO M, ALBRECHT F, AZEVEDO JL AND BARROS NM. 2009. Toxicity of Piper aduncum L. (Piperales: Piperaceae) from the Amazon forest for the cattle tick Rhipicephalus (Boophilus) microplus (Acari: Ixodidae). Vet Parasitol 164: 267-274.

SILVA WC, SOUZA HEM, CORRÊA RS AND RIBEIRO JD. 2007. Atividade inseticida de Piper aduncum L. (Piperaceae) sobre Aetalion sp. (Hemiptera: Aetalionidae), praga de importância econômica no Amazonas. Acta Amazonica 37: 293-298.

SOUSA RMOF, ROSA JS, OLIVEIRA L, CUNHA A and FERNANDES-FERREIRA M. 2015. Activities of Apiaceae essential oils and volatile compounds onhatchability, development, reproduction and nutrition of Pseudaletia unipuncta (Lepidoptera: Noctuidae). Ind Crops Prod 63: 226-237.

SOUTO RNP, HARADA AY, ANDRADE EH AND MAIA JG. 2012. Insecticidal activity of Piper essential oils from the amazon against the fire ant Solenopsis saevissima (Smith) (Hymenoptera: Formicidae). Neotrop Entomol 41: 510-517.

TORRES AL, BARROS R AND OLIVEIRA JV. 2001. Efeito de extratos aquosos de plantas no desenvolvimento de Plutella xylostella (L.) (Lepidoptera: Plutellidae). Neotrop Entomol 30: 151-156.

TRINDADE FTT, STABELI RG, FACUNDO VA, CARDOSO CT, SILVA MA, GIL LHS, SILVA-JARDIM I AND SILVA AA. 2012. Evaluation of larvicidal activity of the methanolic extracts of Piper alatabaccum branches and Piper tuberculatum leaves and compounds isolated against Anopheles darlingi. Braz J Pharmacog 22: 979-984.

TRINDADE RCP, MARQUES IMR, XAVIER HS AND OLIVEIRA JV. 2000. Extrato metanólico da amêndoa da semente de nim e a mortalidade de ovos e lagartas da traçado-tomateiro. Sci Agric (Piracicaba, Braz.) 57: 407-413.

VEIGA JUNIOR VF, PINTO AC AND MACIEL MAM. 2005. Plantas medicinais: cura segura? Quim Nova 28: 519-528.

VOLPE HXL, FAZOLIN M, GARCIA RB, MAGNANI RF, BARBOSA JC AND MIRANDA MP. 2016. Efficacy of essential oil of Piper aduncum against nymphs and adults of Diaphorina citri. Pest Manag Sci 72: 1242-1249.

WILKINSON CF, MURRAY M AND MARCUS CB. 1984. Interaction of ethylenedioxyphenyl compounds with cytochrome P-450 and microsomal oxidation. Rev Biochem Toxicol 6: 27-63. 